\title{
Differences in work injury risk between immigrants and natives: changes since the economic recession in Italy
}

\author{
Massimiliano Giraudo ${ }^{1}$, Antonella Bena ${ }^{1 *}$, Michele Mosca ${ }^{2}$, Elena Farina ${ }^{1}$, Roberto Leombruni ${ }^{2}$ and \\ Giuseppe Costa ${ }^{1,3}$
}

\begin{abstract}
Background: It is known that occupational injury rates are higher for immigrant than for native workers, however the effects of the economic cycles on these differences has not been assessed to date. The aim of the paper is to test if the crisis has the same mechanism of selection in the two groups by comparing injury rates in 2005 (before the crisis) and in 2010 (after the crisis).

Methods: The Work History Italian Panel-Salute integrated database was interrogated to identify employment contracts in the metalworking and construction industries for the years 2005 and 2010 and the occupational injuries. A definition based on the type of injury, less likely to be biased by underreporting, was used to select serious events. Immigrants and natives were matched using the propensity score method and injury rates were calculated in the two years. Analyses were stratified by industry.

Results: In the metalworking industry injury rates slightly increased over time for both groups, and were higher among immigrant than native workers in both 2005 and 2010. In the construction industry the 2005 injury rate was the same in the two groups, and there was a negative trend over time in both groups. However the decline in the 2010 injury rate for Italian workers was much larger, which led to a considerable increase of the incidence rate ratio of immigrants with respect to native (IRR 3.83, 95\% Cl 2.52-5.75).

Conclusions: The economic recession had an impact on the risk of workplace injury. Though the main observed factors (18 variables) usually reported in literature to explain the higher injury rates of the immigrant workers were controlled through the matching, there were still differences between immigrants and natives. The main reason is that immigrants continue to be assigned to the more dangerous jobs and the more dangerous tasks within these job. Furthermore, also differences in the perception of workplace injury risks, linguistic barriers, and cultural factors may have a role in explaining this gap.
\end{abstract}

Keywords: Immigrant workers, Occupational injuries, Economic crisis, Work and health histories Italian panel, Longitudinal study

\footnotetext{
* Correspondence: antonella.bena@epi.piemonte.it

'Department of Epidemiology, ASL TO3, via Sabaudia 164, 10095 Grugliasco,

Italy

Full list of author information is available at the end of the article
}

(C) The Author(s). 2019 Open Access This article is distributed under the terms of the Creative Commons Attribution 4.0 International License (http://creativecommons.org/licenses/by/4.0/), which permits unrestricted use, distribution, and reproduction in any medium, provided you give appropriate credit to the original author(s) and the source, provide a link to the Creative Commons license, and indicate if changes were made. The Creative Commons Public Domain Dedication waiver (http://creativecommons.org/publicdomain/zero/1.0/) applies to the data made available in this article, unless otherwise stated. 


\section{Background}

The risk of total and fatal occupational injury is generally higher for immigrant than for native workers, although some study results are discordant $[1,2]$. The higher injury rates among immigrant workers in Italy differ in the relative risk depending on worker nationality and economic sector [3]. The reasons mainly regard the assignment of immigrant workers to the more dangerous jobs and the more dangerous tasks within these jobs, and the transient nature of their employment situation (immigrant workers transition between unemployment, underemployment, and informal labour force participation) [4]. Furthermore, immigrant workers are more often employed by small firms where the risk of fatal and serious workplace accidents is higher than in large companies [5]. Other factors are the differences in the perception of workrelated risks, linguistic barriers, and cultural factors that reduce the effectiveness of training [6]. As in many highly developed countries, [7] so too in Italy immigrant workers are more frequently employed under fixed-term contracts [8].

Since 2008 Italy has been caught in an economic recession. The unemployment rate rose from $6.1 \%$ in 2007 to $8.4 \%$ in 2010 , while the rate among immigrant workers increased from $8.3 \%$ in 2007 to $11.6 \%$ in 2010 [9]. The employment status of immigrants has worsened, with a greater increase in the share of underemployed immigrant workers [10]. Despite the recession, the number of residence permits issued for labour reasons (which are the migrants' entry channel) continued to grow until 2010 [11, 12]. This was due in part to the entry of Eastern European countries in the European Union in 2008, in part to a persisting, although controversial, need for foreign manpower, which has convinced decision-makers to maintain legal channels relatively open also in times of crisis. Since 2008 Romanians have represented the largest proportion of immigrants, followed by Albanians and Moroccans.

There is a procyclical relationship between economic growth and occupational injuries in the short term. The injury rate rises during periods of economic growth and falls during recessions [13-15]. Also a recent study has shown that in Italy workplace injury rates in manufacturing declined between 1994 and 2012, and this downward trend was further accelerated after 2008 [16]. The main assumptions underlying this association are changes in workforce composition, working conditions, reporting behaviour and mix of employment sectors. Furthermore de la Fuente suggests that the economic recession seems to exert a sort of "natural selection" in the labour market where only the most fit tend to remain employed, with a far lower probability of sustaining a workplace injury [17].
To the best of our knowledge, no studies to date have assessed how the current recession is affecting the work safety of immigrant workers. We know that they start from a disadvantaged condition, but our hypothesis is that the economic crisis has the same mechanisms of selection among immigrants and among natives so the differential in injury rates between the two groups should disappear after the economic crisis. To study this hypothesis we compared work injury rates of immigrant and native workers in 2005 (two years prior to the start of the recession) and in 2010, controlling both from confounders and mediators usually considered in the literature to explain injury risk differences, in order to assess an eventual net impact of the crisis over and above these factors.

\section{Materials and methods}

\section{Definition of immigrant}

To define immigrants a criteria based on the country of birth was used, and two groups were formed: people born in high income countries (HIC, as defined by the World Bank; Italians made up 98\% of this group) and people born in countries with strong migratory pressure (SMPC: Africa; Middle East and Asia excluding Israel, South Korea, and Japan; Latin America; Central and Eastern Europe). This definition of immigration status was developed within a specific project, financed by the Italian Ministry of Health, which had the aim of studying the health of immigrant population [18]. The immigrant population does not therefore correspond to the foreign one. This distinction is useful to detect the subjects that come from more deprived countries, who usually tend to accept worse working conditions.

\section{Data sources}

The Work Histories Italian Panel (WHIP) database contains individual work histories developed from the administrative archives of the National Institute for Social Welfare (INPS). It was built starting from a systematic sample of workers selected every year on the basis of the day of birth (1st and 9th of each month), and it represents the $7 \%$ of the reference population. A career path was reconstructed for each person considering work periods, retirement and unemployment benefits. Currently, the historical series covers the period 1985 to 2012.

The WHIP sample is representative of the workers registered at the INPS, therefore it represents the private sector (manufacturing, construction and services) and does not cover public employment and agriculture. It comprises employees, self-employed and professionals, apart from some specific categories, eg. architects and lawyers, which are not registered at the INPS. The most extensive and complete data regards employees, for 
whom in addition to demographic characteristics, various information on jobs and companies are available.

Using the same sampling criteria (day of birth 1st and 9th of each month), occupational injury claims for absence from work for more than 3 days certified by a physician (mandatory) between 1994 and 2012 were extracted from the archive of the National Insurance Institute for Occupational Injuries (INAIL). Similarly, hospital discharges between 2001 and 2014 were extracted from the archive of the Italian Ministry of Health.

These three archives were then linked via an encrypted unique identifier based on the worker's tax code and the integrated database is called WHIP-Salute. For a more detailed description of the WHIP-Salute database, see Bena et al [19].

The hypothesis underlying the choice of using a sampling frame based on the birth date is that the probability of extracting an individual will be uniform within a given year. However this assumption is not always valid for immigrant workers because they often do not know their exact date of birth and give January 1 on registration in official records in Italy. This generates an oversampling differential by immigrant status that could create bias. To correct this distortion, we assigned a weight to each worker based on his country of birth and using the distribution of the resident population according to the 2011 Italian General Census of Population and Housing [20].

This study doesn't entail an ethical approval. All activities, regardless of their complexity or depth, were conducted in accordance with Italian regulations on privacy (D.Lgs. 101/2018) and with the approval of the national institutes involved. From 2013, the WHIP-Salute database has been included, under the responsibility of the Ministry of Health, in the National Statistics Program that establishes what are the statistical surveys of public interest.

\section{Cohorts of workers}

Starting from the WHIP-Salute database two cohorts of workers were considered, in order to compare a period before and a period after the start of the economic recession. All employment contracts in the metalworking and construction industries held by men, aged between 16 and 55 years, in blue collar jobs or apprentices in 2005 (year before the economic recession) or 2010 (year of the economic recession) were then selected. Permanent, fixed-term contracts, seasonal work, and on-the-job training contracts were all included. On the contrary people that appeared for the first time in the WhipSalute dataset in either 2005 or 2010, were excluded, due to the lack of information on previous career. All restrictions have been made to limit the analysis to the categories where the presence of immigrants is relevant, eg. metalworking and construction industries are the two sectors with the largest foreign worker component ( $47 \%$ of the total).

\section{Propensity score matching}

The intersection between the immigration status and the year of the cohort defines four groups: SMPC workers in 2005 and 2010, HIC workers in 2005 and 2010. To make the four groups comparable a propensity score matching (PSM) was used [21]. This method allows to balance the observable covariates of exposed and unexposed groups. Matching was performed using the "PSMatching" SAS macro [22]. The analytical framework is presented in Fig. 1.

The PSM method was applied in three progressive steps with the specific aim of making all groups similar to the SMPC 2005 (benchmark group). In the first step, SMPC 2005 and HIC 2005 were considered. A logistic model was used to model the probability of being an immigrant worker in 2005, which is the propensity score (PS), Based on the PS value, each HIC worker was matched with an SMPC worker using the Kernel approach [23]. By the same procedure, in the second and third steps, the SMPC workers in 2005 were matched with the SMPC and the HIC workers in 2010. The result of these three steps was a dataset in which the four groups were observationally equal, except for their immigration status and year in which they are observed.

The variables included in all the logistic models to calculate the PS are the main factors available in WHIPSalute which are known to be either possible confounders or mediating factors in the relation between nativity of the worker and injury risk, and which all resulted unbalanced between HIC and SMPC:

- Personal characteristic: only age was included as a continuous variable;

- Variables that describe the employment conditions: skill level (apprentice; blue collar), firm size (yearly average number of employees), geographic location of the firm (according to the country's four administrative areas: Northwest, Northeast, Centre, South, and Islands), month in which the individual entered the cohort, and job tenure (time elapsed from the beginning of the contract and the beginning of the follow-up, continuous variable);

- Variables that describe the work career, calculated considering the 20 years preceding the beginning of the follow-up (2005 or 2010 respectively): prevailing skill level had as employee; having worked as self-employed, artisan or trader; having worked as an employee, selfemployed or professional; cumulative duration of periods of employment; cumulative duration of periods of unemployment; prevailing economic sector in which the 


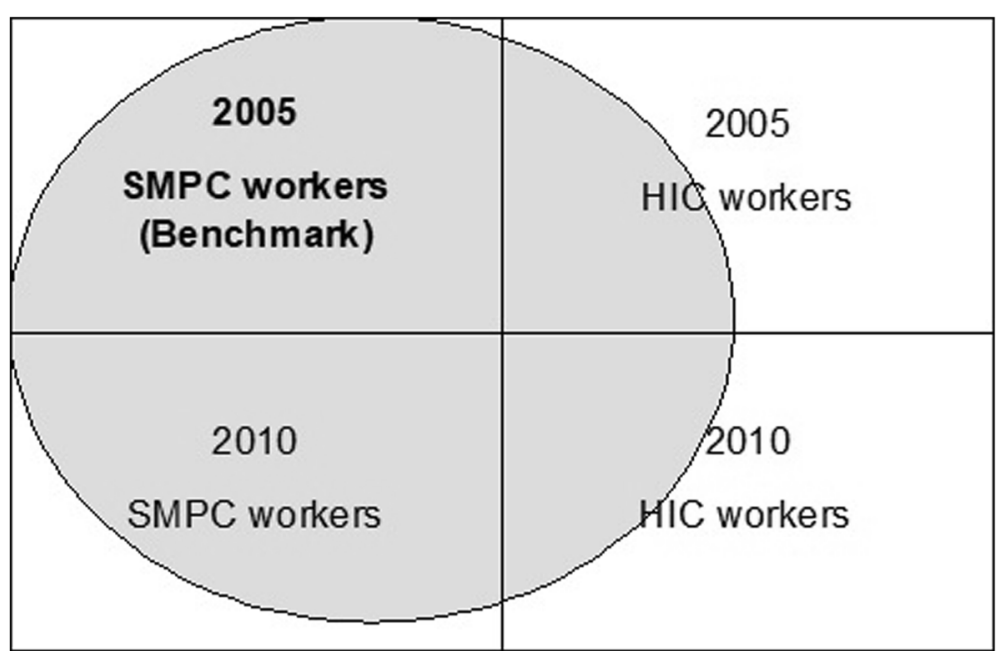

Fig. 1 Analytical framework

worker had worked (metalworking, construction, wholesale and retail trade, transport and storage, financial and real estate, hotel and restaurant, other manufacturing sectors, education and health services, missing data); prevailing firm size where the worker had worked; the prevailing geographic location of the firm where the worker had worked; quartile of wage (which was calculated for the 5 years preceding the beginning of the follow-up).

- Variables that describe health status considering the period preceding the beginning of the follow-up (2005 or 2010 respectively): proportion of weeks of sickness absence and of paid weeks in the 5 years preceding the beginning of the follow-up; number of serious workplace injuries in the 5 years preceding the beginning of the follow-up; number of hospital discharges in the 3 years preceding the beginning of the follow-up.

\section{Statistical analysis}

The outcome of interest was the injury rate. As numerator, all serious workplace injuries recognized by INAIL were selected. For the present analysis an injury was defined serious if: the type of injury was an anatomic loss, a fracture, a foreign body in an eye; or the anatomic part involved was hand, wrist, arms, chest, spinal column, pelvis, hip, knee, ankle, foot; or the event was fatal. Time-at-risk was calculated on the basis of months actually worked, after subtracting all periods of absence from work due to illness or injury and temporary lay-off from paid months.

Injury rates per 1000 person years were calculated. Confidence intervals $(\mathrm{CI})$ were calculated using the bootstrapping method [24]. In brief, the basic idea of bootstrapping is that inference about a population from sample data can be modelled by resampling the sample data and performing inference about a sample from the resampled data. Incidence rate ratios (IRR) were calculated to compare injury rates. The confidence interval of IRR was calculated with Byar's approximation [25]. All analyses were stratified by industry. Statistical analyses were performed using SAS 9.3 (SAS Institute, Carey, NC, USA).

\section{Results}

A total of 181,186 workers were observed (40,735 SMPC and 140,451 HIC). Tables 1 and 2 show the distribution of the main characteristics of the workers by industrial sector before the matching (a complete description is given in the Additional file 1 Material). In both sectors, SMPC workers were younger with respect to HIC (t-test, $p<.0001)$. Moreover they were generally employed by small and medium enterprises located mainly in northern Italy (Pearson's chi-squared test, $\mathrm{p}<.0001$ ) and had a shorter job tenure (t-test, $p<.0001)$.

The HIC workers had a longer working career than the SMPC workers and they received a higher wage ( $\mathrm{t}$ test, $p<.0001)$. Considering only workers in the metalworking industry (Table 1) more HIC workers were employed in the metalworking sector also in the past (84.9\% in 2005 and $86.7 \%$ in 2010) than SMPC workers (77.4\% in 2005 and $83.3 \%$ in 2010). Considering only workers in the construction industry (Table 2) more HIC workers were employed in the construction sector also in the past (81.9\% in 2005 and $86.3 \%$ in 2010) than SMPC workers (84.5\% in 2005 and $92.1 \%$ in 2010). Finally, SMPC workers submitted fewer sick-leave claims than HIC workers (t-test, $p<.0001)$.

The matching method allowed us to link the four groups. Evaluation of the appropriateness of the matched samples and of the success of propensity score modelling is given in the Additional file 2 Material. To summarise, the standardized differences were strongly reduced after the matching and the Sianesi-test [26] confirmed that, 
Table 1 - Main personal, employment, work career characteristics, and health status of workers by immigration status and year of work in the metalworking industry before propensity score matching

\begin{tabular}{|c|c|c|c|c|c|c|c|c|c|}
\hline & & \multicolumn{4}{|l|}{2005} & \multicolumn{4}{|l|}{2010} \\
\hline & & \multicolumn{2}{|l|}{$\mathrm{HIC}^{\mathrm{a}}$} & \multicolumn{2}{|l|}{ SMPC $^{b}$} & \multicolumn{2}{|l|}{$\mathrm{HIC}^{\mathrm{a}}$} & \multicolumn{2}{|l|}{$\mathrm{SMPC}^{\mathrm{b}}$} \\
\hline & & $\begin{array}{l}\text { Person } \\
\text { years }\end{array}$ & $\%$ & $\begin{array}{l}\text { Person } \\
\text { years }\end{array}$ & $\%$ & $\begin{array}{l}\text { Person } \\
\text { years }\end{array}$ & $\%$ & $\begin{array}{l}\text { Person } \\
\text { years }\end{array}$ & $\%$ \\
\hline & & 63,605 & 100 & 7505 & 100 & 53,984 & 100 & 8487 & 100 \\
\hline \multicolumn{10}{|l|}{ Worker characteristics } \\
\hline \multirow[t]{4}{*}{ Age } & $<25$ & 7584 & 11.9 & 796 & 10.6 & 4608 & 8.5 & 793 & 9.3 \\
\hline & $25-34$ & 21,474 & 33.8 & 2742 & 36.5 & 14,859 & 27.5 & 2554 & 30.1 \\
\hline & $35-44$ & 19,729 & 31.0 & 2777 & 37.0 & 19,040 & 35.3 & 3181 & 37.5 \\
\hline & $45-55$ & 14,817 & 23.3 & 1189 & 15.8 & 15,477 & 28.7 & 1958 & 23.1 \\
\hline \multicolumn{10}{|l|}{ Employment } \\
\hline \multirow[t]{5}{*}{ Job tenure (in months) } & $<12$ months & 12,049 & 18.9 & 2586 & 34.5 & 7390 & 13.7 & 1967 & 23.2 \\
\hline & $1-4$ years & 18,887 & 29.7 & 3557 & 47.4 & 14,916 & 27.6 & 3585 & 42.2 \\
\hline & $5-9$ years & 13,499 & 21.2 & 1010 & 13.5 & 11,910 & 22.1 & 2138 & 25.2 \\
\hline & 10-14 years & 7171 & 11.3 & 243 & 3.2 & 8477 & 15.7 & 595 & 7.0 \\
\hline & $\geq 15$ years & 11,998 & 18.9 & 110 & 1.5 & 11,291 & 20.9 & 201 & 2.4 \\
\hline \multirow{4}{*}{$\begin{array}{l}\text { Firm size (yearly average no. of } \\
\text { employees) }\end{array}$} & $1-9$ & 12,515 & 19.7 & 1996 & 26.6 & 10,921 & 20.2 & 2160 & 25.5 \\
\hline & $10-19$ & 9282 & 14.6 & 1561 & 20.8 & 7849 & 14.5 & 1712 & 20.2 \\
\hline & 20-199 & 23,569 & 37.1 & 3024 & 40.3 & 20,096 & 37.2 & 3600 & 42.4 \\
\hline & $>199$ & 18,239 & 28.7 & 924 & 12.3 & 15,118 & 28.0 & 1015 & 12.0 \\
\hline \multirow[t]{4}{*}{ Firm's geographic location } & Northwest & 24,681 & 38.8 & 3111 & 41.5 & 20,131 & 37.3 & 3472 & 40.9 \\
\hline & Northeast & 18,174 & 28.6 & 3198 & 42.6 & 15,757 & 29.2 & 3516 & 41.4 \\
\hline & Central & 8483 & 13.3 & 907 & 12.1 & 7493 & 13.9 & 1047 & 12.3 \\
\hline & South and Islands & 12,267 & 19.3 & 288 & 3.8 & 10,604 & 19.6 & 452 & 5.3 \\
\hline \multicolumn{10}{|c|}{ Working career (in the 20 years preceding the year) } \\
\hline \multirow[t]{3}{*}{ Prevailing skill level } & Apprentice & 5886 & 9.3 & 516 & 6.9 & 4032 & 7.5 & 588 & 6.9 \\
\hline & Blue collar & 56,936 & 89.5 & 6976 & 93.0 & 49,195 & 91.1 & 7876 & 92.8 \\
\hline & White collar & 782 & 1.2 & 12 & 0.2 & 756 & 1.4 & 22 & 0.3 \\
\hline \multirow[t]{5}{*}{ Cumulative duration as employee } & $<12$ months & 1502 & 2.36 & 421 & 5.62 & 671 & 1.2 & 248 & 2.9 \\
\hline & $1-4$ years & 8863 & 13.9 & 3422 & 45.6 & 5736 & 10.6 & 2442 & 28.8 \\
\hline & $5-9$ years & 12,581 & 19.8 & 2123 & 28.3 & 8910 & 16.5 & 3202 & 37.7 \\
\hline & 10-14 years & 16,164 & 25.4 & 1005 & 13.4 & 15,559 & 28.8 & 1747 & 20.6 \\
\hline & $\geq 15$ years & 24,495 & 38.5 & 533 & 7.11 & 23,109 & 42.8 & 848 & 10.0 \\
\hline \multirow{4}{*}{$\begin{array}{l}\text { Quartile of wage in the } 5 \text { years preceding } \\
\text { the beginning of follow-up }\end{array}$} & । & 12,601 & 19.8 & 2765 & 36.8 & 10,083 & 18.7 & 3121 & 36.8 \\
\hline & $\|$ & 14,305 & 22.5 & 2551 & 34 & 12,001 & 22.2 & 2693 & 31.7 \\
\hline & III & 17,285 & 27.2 & 1498 & 20 & 14,732 & 27.3 & 1753 & 20.7 \\
\hline & IV & 19,415 & 30.5 & 691 & 9.21 & 17,169 & 31.8 & 920 & 10.8 \\
\hline \multirow[t]{7}{*}{ Prevailing economic sector } & Metalworking & 53,983 & 84.9 & 5811 & 77.4 & 46,801 & 86.7 & 7072 & 83.3 \\
\hline & Construction & 2329 & 3.66 & 406 & 5.41 & 1970 & 3.6 & 442 & 5.2 \\
\hline & $\begin{array}{l}\text { Wholesale and retail } \\
\text { trade }\end{array}$ & 1743 & 2.74 & 109 & 1.46 & 1196 & 2.2 & 92 & 1.1 \\
\hline & $\begin{array}{l}\text { Transport, storage, and } \\
\text { communication }\end{array}$ & 417 & 0.65 & 100 & 1.33 & 313 & 0.6 & 55 & 0.6 \\
\hline & Financial and real estate & 998 & 1.57 & 465 & 6.2 & 926 & 1.7 & 425 & 5.0 \\
\hline & Hotel and restaurant & 339 & 0.53 & 100 & 1.33 & 217 & 0.4 & 66 & 0.8 \\
\hline & Other manufacturing & 3170 & 4.98 & 411 & 5.47 & 2113 & 3.9 & 271 & 3.2 \\
\hline
\end{tabular}


Table 1 - Main personal, employment, work career characteristics, and health status of workers by immigration status and year of work in the metalworking industry before propensity score matching (Continued)

\begin{tabular}{|c|c|c|c|c|c|c|c|c|c|}
\hline & & \multicolumn{4}{|l|}{2005} & \multicolumn{4}{|l|}{2010} \\
\hline & & \multicolumn{2}{|l|}{$\mathrm{HIC}^{\mathrm{a}}$} & \multicolumn{2}{|l|}{$\mathrm{SMPC}^{\mathrm{b}}$} & \multicolumn{2}{|l|}{$\mathrm{HIC}^{\mathrm{a}}$} & \multicolumn{2}{|l|}{$\mathrm{SMPC}^{\mathrm{b}}$} \\
\hline & & $\begin{array}{l}\text { Person } \\
\text { years }\end{array}$ & $\%$ & $\begin{array}{l}\text { Person } \\
\text { years }\end{array}$ & $\%$ & $\begin{array}{l}\text { Person } \\
\text { years }\end{array}$ & $\%$ & $\begin{array}{l}\text { Person } \\
\text { years }\end{array}$ & $\%$ \\
\hline & & 63,605 & 100 & 7505 & 100 & 53,984 & 100 & 8487 & 100 \\
\hline & $\begin{array}{l}\text { Instruction and health } \\
\text { services }\end{array}$ & 200 & 0.31 & 28 & 0.38 & 162 & 0.3 & 22 & 0.3 \\
\hline & Missing & 428 & 0.67 & 75 & 0.99 & 285 & 0.5 & 42 & 0.5 \\
\hline \multicolumn{10}{|l|}{$\begin{array}{l}\text { Health status in the } 5 \text { years preceding the } \\
\text { beginning of follow-up }\end{array}$} \\
\hline \multirow{8}{*}{$\begin{array}{l}\text { Ratio between no. of weeks of sickness } \\
\text { absence and total paid weeks (in \%) in } \\
\text { the } 5 \text { years preceding the beginning } \\
\text { of follow-up }\end{array}$} & Missing & 123 & 0.19 & 7 & 0.1 & 109 & 0.2 & 18 & 0.2 \\
\hline & 0 & 34,006 & 53.5 & 4474 & 59.6 & 29,477 & 54.6 & 5216 & 61.5 \\
\hline & $1-4$ & 21,352 & 33.6 & 2182 & 29.1 & 18,232 & 33.8 & 2539 & 29.9 \\
\hline & $5-9$ & 5788 & 9.1 & 566 & 7.5 & 4486 & 8.3 & 520 & 6.1 \\
\hline & 10-19 & 1975 & 3.1 & 231 & 3.1 & 1469 & 2.7 & 163 & 1.9 \\
\hline & $20-49$ & 344 & 0.54 & 37 & 0.5 & 202 & 0.4 & 30 & 0.4 \\
\hline & $50-74$ & 11 & 0.02 & 4 & 0.1 & 6 & 0.0 & 2 & 0.0 \\
\hline & $75-100$ & 6 & 0.01 & 1 & 0.0 & 4 & 0.0 & 0 & 0.0 \\
\hline
\end{tabular}

a: HIC - high income country b: SMPC - strong migratory pressure country

after matching, there were no systematic differences in the distribution of covariates between groups. The pseudo-R2 calculated on the matched sample was close to zero.

Table 3 presents the injury rates and IRR by immigration status in the metalworking sector after PSM. The workplace injury rates of the HIC workers were generally lower than those of the SMPC workers, and this difference was statistically significant. Looking at the trend over time, the 2010 rate was higher than the 2005 rate for both the SMPC and the HIC workers. The increase was not statistically significant, indicating that the difference in risk between the SMPC and the HIC workers remained unchanged over time.

In the construction industry, the 2005 injury rate was the same for the HIC workers as for the SMPC workers (Table 4). The injury rate for the SMPC workers didn't change over time (IRR SMPC 2010 vs. SMPC 2005 0.84; 95\% confidence interval (CI) 0.65-1.09), whereas a drastic decline in the 2010 injury rate was noted for the HIC workers, with the effect that the risk difference between the SMPC and HIC workers changed significantly over time. While the 2005 injury rates were substantially identical, the IRR between the SMPC and the HIC groups was 3.83 in 2010 (95\% CI 2.52-5.75).

\section{Discussion}

We studied the hypothesis that economic crisis had the same mechanisms of selection among SMPC workers and HIC workers and that, taking into account the main factors that could be associated with health and employment conditions, the differential in injury rates between the two groups would tend to disappear from before to after the recession. With this aim, we compared the injury rates between groups and over time.

To make the comparison as free as possible from potential source of bias we applied some methodological choices: we used the PSM method to control for differences between groups and variations in the workforce composition over time; we considered only serious injuries to control for the phenomenon of underreporting; and we stratified the analyses by economic sector in which immigrant are mainly represented.

The descriptive analysis underlines the marked differences between SMPC and HIC workers and the changes in the workforce composition since the start of the economic recession. These results confirm the need to use a method to control for confounding in order to compare the groups of workers. The average age of both the SMPC and the HIC groups rose between 2005 and 2010. Selection of experienced workers during the recession could be seen in the increase in the average job tenure. This finding was also present when we observed how the distribution of the cumulative duration as employee changed between 2005 and 2010. These results are consistent with the official statistics on Italian labour market [9].

The variables included in the regression model are the main factors commonly used to explain injury risk differences between SMPC and HIC workers. They represent the principal characteristics of employment conditions, an individual's work career, and health status. Among other factors, we wish to emphasize the use of the "job tenure" variable, which is an important determinant 
Table 2 Main personal, employment, work career characteristics, and health status of workers by immigration status and year of work in the construction industry before propensity score matching

\begin{tabular}{|c|c|c|c|c|c|c|c|c|c|}
\hline & & \multicolumn{4}{|l|}{2005} & \multicolumn{4}{|l|}{2010} \\
\hline & & \multicolumn{2}{|l|}{$\mathrm{HIC}^{\mathrm{a}}$} & \multicolumn{2}{|l|}{$\mathrm{SMPC}^{\mathrm{b}}$} & \multicolumn{2}{|l|}{$\mathrm{HIC}^{\mathrm{a}}$} & \multicolumn{2}{|l|}{$\mathrm{SMPC}^{\mathrm{b}}$} \\
\hline & & $\begin{array}{l}\text { Person } \\
\text { years }\end{array}$ & $\%$ & $\begin{array}{l}\text { Person } \\
\text { years }\end{array}$ & $\%$ & $\begin{array}{l}\text { Person } \\
\text { years }\end{array}$ & $\%$ & $\begin{array}{l}\text { Person } \\
\text { years }\end{array}$ & $\%$ \\
\hline & & 45,661 & 100 & 11,182 & 100 & 40,142 & 100 & 12,857 & 100 \\
\hline \multicolumn{10}{|l|}{ Worker characteristics } \\
\hline \multirow[t]{4}{*}{ Age } & $<25$ & 8064 & 17.7 & 1710 & 15.3 & 5297 & 13.2 & 1749 & 13.6 \\
\hline & $25-34$ & 13,672 & 29.9 & 4658 & 41.7 & 11,103 & 27.7 & 4990 & 38.8 \\
\hline & $35-44$ & 13,363 & 29.3 & 3453 & 30.9 & 12,324 & 30.7 & 4232 & 32.9 \\
\hline & $45-55$ & 10,562 & 23.1 & 1362 & 12.2 & 11,418 & 28.4 & 1887 & 14.7 \\
\hline \multicolumn{10}{|l|}{ Employment } \\
\hline \multirow[t]{5}{*}{ Job tenure (in months) } & $<12$ months & 20,095 & 44.0 & 6527 & 15.3 & 15,270 & 38.0 & 5966 & 46.4 \\
\hline & $1-4$ years & 15,922 & 34.9 & 4102 & 41.7 & 13,813 & 34.4 & 5184 & 40.3 \\
\hline & $5-9$ years & 5456 & 11.9 & 449 & 30.9 & 6176 & 15.4 & 1445 & 11.2 \\
\hline & 10-14 years & 2011 & 4.4 & 94 & 12.2 & 2511 & 6.3 & 207 & 1.6 \\
\hline & $\geq 15$ years & 2176 & 4.8 & 11 & 0.1 & 2373 & 5.9 & 56 & 0.4 \\
\hline \multirow{4}{*}{$\begin{array}{l}\text { Firm size (yearly average no. of } \\
\text { employees) }\end{array}$} & $1-9$ & 24,249 & 53.1 & 7042 & 63.0 & 21,803 & 54.3 & 7609 & 59.2 \\
\hline & $10-19$ & 8706 & 19.1 & 1797 & 16.1 & 7437 & 18.5 & 2312 & 18.0 \\
\hline & 20-199 & 10,643 & 23.3 & 2171 & 19.4 & 9247 & 23.0 & 2788 & 21.7 \\
\hline & $>199$ & 2063 & 4.5 & 172 & 1.5 & 1655 & 4.1 & 148 & 1.2 \\
\hline \multirow[t]{4}{*}{ Firm's geographic location } & Northwest & 11,852 & 26.0 & 4423 & 39.6 & 9881 & 24.6 & 4885 & 38.0 \\
\hline & Northeast & 9100 & 19.9 & 3194 & 28.6 & 7416 & 18.5 & 3091 & 24.0 \\
\hline & Central & 8191 & 17.9 & 2719 & 24.3 & 7108 & 17.7 & 3601 & 28.0 \\
\hline & South and Islands & 16,518 & 36.2 & 846 & 7.6 & 15,736 & 39.2 & 1279 & 10.0 \\
\hline \multicolumn{10}{|l|}{$\begin{array}{l}\text { Working career (in the } 20 \text { years } \\
\text { preceding the year) }\end{array}$} \\
\hline \multirow[t]{3}{*}{ Prevailing skill level } & Apprentice & 7522 & 16.5 & 991 & 8.9 & 5266 & 13.1 & 1683 & 13.1 \\
\hline & Blue collar & 37,730 & 82.6 & 10,183 & 91.1 & 34,484 & 85.9 & 11,167 & 86.9 \\
\hline & White collar & 409 & 0.9 & 7 & 0.1 & 392 & 1.0 & 7 & 0.1 \\
\hline \multirow[t]{5}{*}{ Cumulative duration as employee } & $<12$ months & 2443 & 5.4 & 1039 & 9.3 & 1334 & 3.3 & 944 & 7.3 \\
\hline & $1-4$ years & 10,283 & 22.5 & 6485 & 58 & 7576 & 18.9 & 5182 & 40.3 \\
\hline & $5-9$ years & 10,714 & 23.5 & 2512 & 22.5 & 9684 & 24.1 & 4280 & 33.3 \\
\hline & 10-14 years & 10,655 & 23.3 & 731 & 6.54 & 10,108 & 25.2 & 1425 & 11.1 \\
\hline & $\geq 15$ years & 11,565 & 25.3 & 415 & 3.71 & 11,439 & 28.5 & 1026 & 8.0 \\
\hline \multirow{4}{*}{$\begin{array}{l}\text { Quartile of wage in the } 5 \text { years preceding } \\
\text { the beginning of follow-up }\end{array}$} & 1 & 10,918 & 23.9 & 2609 & 23.3 & 9070 & 22.6 & 3164 & 24.6 \\
\hline & $\|$ & 9174 & 20.1 & 3531 & 31.6 & 8316 & 20.7 & 3657 & 28.4 \\
\hline & III & 10,953 & 24 & 3154 & 28.2 & 9461 & 23.6 & 3667 & 28.5 \\
\hline & IV & 14,615 & 32 & 1888 & 16.9 & 13,295 & 33.1 & 2370 & 18.4 \\
\hline \multirow[t]{6}{*}{ Prevailing economic sector } & Metalworking & 2692 & 5.9 & 450 & 4.02 & 1792 & 4.5 & 312 & 2.4 \\
\hline & Construction & 37,376 & 81.9 & 9446 & 84.5 & 34,622 & 86.3 & 11,845 & 92.1 \\
\hline & $\begin{array}{l}\text { Wholesale and retail } \\
\text { trade }\end{array}$ & 1137 & 2.49 & 169 & 1.51 & 785 & 2.0 & 89 & 0.7 \\
\hline & $\begin{array}{l}\text { Transport, storage, and } \\
\text { communication }\end{array}$ & 559 & 1.22 & 118 & 1.06 & 389 & 1.0 & 72 & 0.6 \\
\hline & Financial and real estate & 592 & 1.3 & 292 & 2.61 & 494 & 1.2 & 181 & 1.4 \\
\hline & Hotel and restaurant & 422 & 0.92 & 152 & 1.36 & 310 & 0.8 & 79 & 0.6 \\
\hline
\end{tabular}


Table 2 Main personal, employment, work career characteristics, and health status of workers by immigration status and year of work in the construction industry before propensity score matching (Continued)

\begin{tabular}{|c|c|c|c|c|c|c|c|c|c|}
\hline & & \multicolumn{4}{|l|}{2005} & \multicolumn{4}{|l|}{2010} \\
\hline & & \multicolumn{2}{|l|}{$\mathrm{HIC}^{\mathrm{a}}$} & \multicolumn{2}{|l|}{$\mathrm{SMPC}^{\mathrm{b}}$} & \multicolumn{2}{|l|}{$\mathrm{HIC}^{\mathrm{a}}$} & \multicolumn{2}{|l|}{$\mathrm{SMPC}^{\mathrm{b}}$} \\
\hline & & $\begin{array}{l}\text { Person } \\
\text { years }\end{array}$ & $\%$ & $\begin{array}{l}\text { Person } \\
\text { years }\end{array}$ & $\%$ & $\begin{array}{l}\text { Person } \\
\text { years }\end{array}$ & $\%$ & $\begin{array}{l}\text { Person } \\
\text { years }\end{array}$ & $\%$ \\
\hline & & 45,661 & 100 & 11,182 & 100 & 40,142 & 100 & 12,857 & 100 \\
\hline & Other manufacturing & 2042 & 4.47 & 394 & 3.53 & 1330 & 3.3 & 199 & 1.6 \\
\hline & $\begin{array}{l}\text { Instruction and health } \\
\text { services }\end{array}$ & 338 & 0.74 & 32 & 0.29 & 206 & 0.5 & 21 & 0.2 \\
\hline & Missing & 502 & 1.1 & 128 & 1.15 & 214 & 0.5 & 58 & 0.5 \\
\hline \multicolumn{10}{|l|}{$\begin{array}{l}\text { Health status in the } 5 \text { years preceding } \\
\text { the beginning of follow-up }\end{array}$} \\
\hline \multirow{8}{*}{$\begin{array}{l}\text { Ratio between no. of weeks of sickness } \\
\text { absence and total paid weeks (in \%) in } \\
\text { the } 5 \text { years preceding the beginning } \\
\text { of follow-up }\end{array}$} & Missing & 401 & 0.88 & 24 & 0.2 & 340 & 0.8 & 73 & 0.6 \\
\hline & 0 & 26,085 & 57.1 & 7959 & 71.2 & 23,018 & 57.3 & 9264 & 72.0 \\
\hline & $1-4$ & 12,627 & 27.7 & 2074 & 18.5 & 11,506 & 28.7 & 2570 & 20.0 \\
\hline & $5-9$ & 4019 & 8.8 & 683 & 6.1 & 3460 & 8.6 & 629 & 4.9 \\
\hline & $10-19$ & 1947 & 4.26 & 322 & 2.9 & 1425 & 3.5 & 244 & 1.9 \\
\hline & $20-49$ & 527 & 1.15 & 105 & 0.9 & 375 & 0.9 & 71 & 0.6 \\
\hline & $50-74$ & 42 & 0.09 & 12 & 0.1 & 13 & 0.0 & 3 & 0.0 \\
\hline & 75-100 & 13 & 0.03 & 3 & 0.0 & 6 & 0.0 & 4 & 0.0 \\
\hline
\end{tabular}

a: HIC - high income country b: SMPC - strong migratory pressure country

of the risk of work-related injury. Most published research provides evidence that newly hired workers - whatever the contract type - are more likely to sustain an injury than those with a longer job tenure, even after taking into account background variables and previous experience $[27,28]$. In a context where labour market flexibility is increasing and changing jobs is becoming more common, workers repeatedly find themselves working in an initially "high-risk" period. This precarious employment situation is particular to immigrant workers [29].

During the recession, the mean number of weeks of sickness absence registered by INPS decreased for the SMPC and the HIC workers in both the metalworking and the construction industries. This change can be interpreted as an increase of presenteeism in the workplace, especially among the SMPC workers [30]. To take into account this phenomenon we decided to use only a subset of serious injury which are unlikely to be underreported. In general, serious injury rates are less affected by underreporting with respect to minor injuries or total injuries
$[13,31]$. However, different definition of seriousness can be adopted, which can lead to different level of underreporting. The definition used in this paper to identify serious injuries avoid using time off from work, often used as a proxy of injury severity, since there were reported practices of early return to work for foreign workers or underreporting for events with a long prognosis [32].

Finally all analyses were stratified by sectors because the association and the mechanisms through which the business cycle affects the incidence of workplace injuries may differ across industries [33].

Results presented in Tables 3 and 4 provide many food for thought.

In the metalworking industry (Table 3), for both groups of workers injury rates grown a little over time, even if the difference was not statistically significant. Though we took into account the workers' principal characteristics, the risk differentials between the SMPC and the HIC groups from before to after the crisis was the same. This indicate that PSM allowed to manage the confounding related to

Table 3 Injury rate per 1000 workers and Incidence Rate Ratio (IRR) (reference: SMPC 2005) in the metalworking industry after propensity score matching [IRR: incidence rate ratio; $\mathrm{Cl}=$ confidence interval]

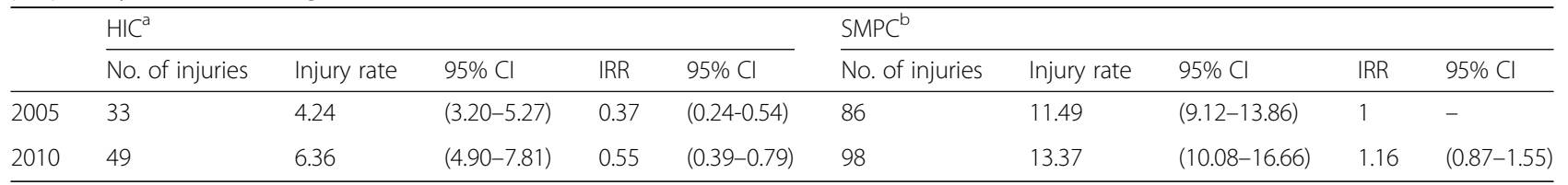

a: HIC - high income country b: SMPC - strong migratory pressure country 
Table 4 Injury rate per 1000 workers and Incidence Rate Ratio (IRR) (reference: SMPC 2005) in the construction industry after propensity score matching [IRR: incidence rate ratio; $\mathrm{Cl}=$ confidence interval]

\begin{tabular}{|c|c|c|c|c|c|c|c|c|c|c|}
\hline & \multicolumn{5}{|l|}{$H I C^{a}$} & \multicolumn{5}{|l|}{$\mathrm{SMPC}^{\mathrm{b}}$} \\
\hline & No. of injuries & Injury rate & $95 \% \mathrm{Cl}$ & IRR & $95 \% \mathrm{Cl}$ & No. of injuries & Injury rate & $95 \% \mathrm{Cl}$ & IRR & $95 \% \mathrm{Cl}$ \\
\hline 2005 & 33 & 13.34 & $(6.12-20.56)$ & 1.19 & $(0.94-1.50)$ & 125 & 11.24 & $(9.47-13.00)$ & 1 & - \\
\hline 2010 & 49 & 2.47 & $(1.85-3.10)$ & 0.22 & $(0.15-0.33)$ & 103 & 9.46 & $(6.71-12.21)$ & 0.84 & $(0.65-1.09)$ \\
\hline
\end{tabular}

a: HIC - high income country b: SMPC - strong migratory pressure country

changes in workforce composition, but also that mechanisms of selection determined by unmeasured factors were the same in both groups. Injury rates for HIC workers remain lower than those of SMPC both before and after the recession (IRR 0.55 ; 95\% CI 0.39-0.79). This may be explained by differences in the level of education, the perception of job-related risk, the knowledge of the Italian language and the participation in training courses. Furthermore, immigrant workers may find it more difficult to adapt themselves to the work organization [34]. Another important factor to consider is the assignment of immigrants to the more dangerous jobs and to the more dangerous tasks within these jobs [4]. Also, the possibility of negotiating between such tasks among SMPC workers is probably lower as compared to HIC workers.

No change in the workplace injury rates for SMPC workers over time was noted in the construction industry (IRR 0.84; 95\% CI 0.65-1.09) after matching (Table 4). This confirms that the risk differences were nullified between the SMPC workers in 2005 and those with the same characteristics in 2010. At the same time in 2005, the risk of injury between SMPC and HIC workers was the same. The unexpected result was the drop in the construction injury rate of the HIC workers from 2005 to 2010, with a resulting rise in the risk differential between the SMPC and the HIC workers (IRR 0.22; 95\% CI 0.15-0.33). Although the PSM selected workers of the HIC group with characteristics similar to the workers of the SMPC group in 2005, selection in the workforce also occurred during the economic recession. For example, some workers had to transition from contracted employment to being self-employed or entering informal work. In addition, employers tend to assign the most dangerous tasks to self-employed workers. This phenomenon involves both immigrant and native workers [35]. Our hypothesis is that there was a very strong workforce selection among the HIC workers with characteristics similar to those of SMPC workers; therefore, people still employed as employees in 2010 had the "best" profile also in terms of health, and this may have contributed to the lower injury rates. Moreover, immigrant workers, driven by economic necessity, were still more likely to accept poor working conditions while Italian workers could be more selective in their options and choices.
The strengths of this study are the main characteristics of the WHIP-Salute database: national representativeness and longitudinal nature and high quality data that allowed us to describe the characteristics of workforce participation in great detail. Most countries do not have adequate national systems that monitor key occupational health problems of immigrants, and most official and nonofficial statistics do not disaggregate migratory flows by age, gender, ethnicity, and social class.

Another strength is the use of the PSM method in the analysis. As we documented, there were large differences between HIC and SMPC workers in the exposure to many important risk factors for work injuries. To properly control for all these factors with a multiple regression model would have forced us to make strong assumptions regarding the type of association of each of them with the health outcome (linear, quadratic, etc.) and about possible interaction between them, resulting in possible miss-specification biases. The use of the PSM method was successful in creating comparison groups which were similar with respect to all those characteristics, which allowed us to interpret the residual differences we found in injury risks just to being before or after the crisis, and being HIC or SMPC workers.

The main limitation of the study regards the external validity of the results. Our research was restricted to male workers employed as blue collars or apprentices, aged between 16 and 55 years, in the metalworking or construction sector. Furthermore we excluded workers seen for the first time in the WHIP-Salute database in either the 2005 or 2010. The results for this worker category are reliable, but to verify whether our conclusions can be generalized, the analysis needs to be extended to other economic sectors not considered in this analysis, to women, and to the selfemployed.

Another limitation is that the WHIP-Salute database contains information only on workers registered at the INPS. As such, it does not comprise the entire immigrant population in Italy, which also includes illegal workers and immigrants without official documents known to be at high risk of workplace accidents [32]. Furthermore, we have no information about the immigrant worker's work career prior to his arrival in Italy. This can lead to underestimate the person's work experience, which should have a protective effect on the risk 
of injury. Therefore matching a SMPC worker who seems without experience with a real new HIC worker can result in an underestimation of the IRR. This problem is partly mitigated considering the age, which is correlated with experience.

\section{Conclusions}

Our study compares workplace injury rates between SMPC workers and HIC workers for 2005 and 2010.

Focusing on the comparisons of interest, between groups and over time, we highlight two main conclusions.

The first is that, regardless of the level in 2005, in 2010 HIC workers are protected with respect to SMPC workers in terms of injury rates, in both metalworking and construction industry. The second is that the dynamic of the impact of the economic crisis is the same in HIC and SMPC workers within the metalworking industry, whereas in the construction industry injury rates of HIC workers had a much greater decline than SMPC workers.

Since we controlled for the main observed factors (18 variables) usually reported in literature to explain the higher injury rates of the immigrant workers, the reasons for the persistence of differences have to be found elsewhere. In our opinion, the main reason is that immigrant workers are assigned to do the more dangerous jobs and the more dangerous tasks within these job. Furthermore, also differences in the perception of workplace injury risks, linguistic barriers, and cultural factors may have a role in explaining this gap.

The study of the mechanisms that explain the differential health of immigrant workers has been identified as a priority for research, and this issue is indicated as a priority for a global agenda in occupational health [36, 37]. The Whip-Salute database allowed us to analyse high quality data in great detail.

These results represent an initial step in the analysis of the effects of the current economic recession on the risk of occupational injury by comparing the condition of immigrant workers before and during the recession. A future area of focus should examine how work safety has changed for immigrant workers, considering also specific country of birth, and the transformations that immigration flows have produced.

\section{Additional files}

Additional file 1: Characteristics of workers by immigration status and year of work before the PS matching (DOCX $34 \mathrm{~kb}$ )

Additional file 2: Appropriateness of the matched samples (DOCX $36 \mathrm{~kb}$ )

\section{Abbreviations}

$\mathrm{Cl}$ : Confidence interval; HIC: highly developed countries as defined by the World Bank; INAIL: Italian workers compensation authority; INPS: Italian National Social Security Institute; IRR: Incidence rate ratio; ISTAT: Italian National Institute of Statistics; PS: propensity score; PSM: propensity score matching; SMPC: countries with strong migratory pressure; WHIPSalute: Work and Health Histories Italian Panel-Health

\section{Acknowledgements}

MG's work was partially supported by the Masters Degree Course in Epidemiology, University of Turin. The authors thank Prof. Emilio Reyneri (University of Milano-Bicocca) and Dr. Roberto Quaranta (Collegio Carlo Alberto-Turin) for their valuable advice that made this study possible.

\section{Authors' contribution}

MG performed all the statistical analyses and wrote the paper. AB, MM, EF, $\mathrm{RL}$ advised on the methodological choices, read and commented on the analyses and the manuscript. GC read and commented on the paper. Each author is confident in the validity of this work, has reviewed the final version of the manuscript and approves it for submission.

\section{Funding}

The research was supported in part by grants from the Italian Ministry of Health - CCM project. The funding body had no role in study design; collection, analysis, and interpretation of data; writing the manuscript; and the decision to submit the manuscript for publication.

\section{Availability of data and materials}

The datasets generated during and/or analysed during the current study are not publicly available, but are available from the corresponding author on reasonable request. From 2013, the WHIP-Salute database has been included, under the responsibility of the Ministry of Health, in the National Statistics Program (NSP) that establishes what are the statistical surveys of public interest. Our institutions are included in the NSP form with the role of developer of the final database, so the data that we used was openly available to us. The Ministry of Health releases microdata files for research purposes, upon request based on a research protocol and after authorization of the Italian Data Protection Authority.

\section{Ethics approval and consent to participate}

not applicable. Informed consent was not necessary. All activities, regardless of their complexity or depth, were conducted in accordance with Italian regulations on privacy (D.Lgs. 101/2018) and with the approval of the national institutes involved. Since WHIP-Salute database has been included, under the responsibility of the Ministry of Health, in the National Statistics Program (NSP) with the code SAL-00054 the Guarantor of privacy had approved the construction and the use of this database. The current NSP 2017-2019 was approved with a Decree of the President of the Republic: https://www.gazzettaufficiale.it/eli/gu/2018/03/20/66/so/12/sg/pdf

\section{Consent for publication}

not applicable.

\section{Competing interests}

The authors declare that they have no competing interests.

\section{Author details}

'Department of Epidemiology, ASL TO3, via Sabaudia 164, 10095 Grugliasco, Italy. ${ }^{2}$ Department of Economics Cognetti de Martiis, University of Turin, Lungo Dora Siena, 100 A, 10153 Turin, Italy. ${ }^{3}$ Department of Clinical and Biological Sciences, University of Turin, Regione Gonzole 10, 10043 Orbassano, Italy.

Received: 12 December 2018 Accepted: 16 June 2019

Published online: 27 June 2019

\section{References}

1. Biering K, Lander F, Rasmussen K. Work injuries among migrant workers in Denmark. Occup Environ Med. 2017;74:235-42. https://doi.org/10.1136/ oemed-2016-103681.

2. Ahonen EQ, Benavides FG, Benach J. Immigrant populations, work and health - a systematic literature review. Scand J Work Environ Health. 2007; 33(2):96-104. https://doi.org/10.5271/sjweh.1112.

3. Giraudo M, Bena A, Costa G. Migrant workers in Italy: an analysis of injury risk taking into account occupational characteristics and job tenure. BMC Public Health. 2017;17(1):351. https://doi.org/10.1186/s12889-017-4240-9. 
4. Schenker M. A global perspective of migration and occupational health. Am J Ind Med. 2010;53(4):329-37. https://doi.org/10.1002/ajim.20834.

5. Fabiano B, Currò F, Pastorino R. A study of the relationship between occupational injuries and firm size and type in the Italian industry. Saf Sci. 2004;42:587-600. https://doi.org/10.1016/j.ssci.2003.09.003.

6. Orrenius PM, Zavodny M. Do immigrants work in riskier jobs? Demography. 2009:46(3):535-51. https://doi.org/10.1353/dem.0.0064.

7. Porthé V, Ahonen E, Vázquez ML, Pope C, Agudelo AA, García AM, et al. Extending a model of precarious employment: a qualitative study of immigrant workers in Spain. Am J Ind Med. 2010;53(4):417-24. https://doi. org/10.1002/ajim.20781.

8. Fullin G, Reyneri E. Low unemployment and bad jobs for new immigrants in Italy. Int Migr. 2011;49:118-47. https://doi.org/10.1111/j.1468-2435.2009. 00594.x.

9. Italian National Institute of Statistics (ISTAT). Labour Force Survey 2016 Available at: http://dati.istat.it/. Accessed July 20, 2017.

10. Italian National Institute of Statistics (ISTAT). (Unemployed, inactive, underemployed) Italian. 2013. Available at: http://www.istat.it/it/archivio/ 87376. Accessed July 20, 2017.

11. Pastore F, Villosio C. Nevertheless attracting... Italy and Immigration in Times of Crisis. Laboratorio Revelli. 2011, Working paper no. 106.

12. Italian National Institute of Statistics (ISTAT). Foreign resident population by sex and year of birth. 2016. Available at: http://demo.istat.it/index.html. Accessed July 20, 2017.

13. Davies $R$, Jones $P$, Nuñez I. The impact of the business cycle on occupational injuries in the UK. Soc Sci Med. 2009;69:178-82. https://doi. org/10.1016/j.socscimed.2009.04.033.

14. Nielsen $\mathrm{K}$, Lander F, Lauritsen JM. The relationship between macroeconomic and industry-specifc business cycle indicators and workrelated injuries among Danish construction workers. Occup Environ Med. 2015;72:271-6. https://doi.org/10.1136/oemed-2014-102290.

15. Fernández-Muñiz B, Montes-Peón JM, Vázquez-Ordás CJ. Occupational accidents and the economic cycle in Spain 1994-2014. Saf Sci. 2016;106: 273-84. https://doi.org/10.1016/j.ssci.2016.02.029.

16. Farina $E$, Giraudo $M$, Costa $G$, Bena A. Injury rates and economic cycles in the Italian manufacturing sector. Occup Med (Lond). 2018:68:459-63. https://doi.org/10.1093/occmed/kqy102.

17. de la Fuente VS, L, López MA, González IF, Alcántara OJ, Ritzel DO. The impact of the economic crisis on occupational injuries. J Saf Res 2014; 48: 77-85. doi: https://doi.org/10.1016/j.jsr.2013.12.007.

18. Carletti P (ed.). La salute della popolazione immigrata: metodologia di analisi. Progetto: Promozione della salute della popolazione immigrata in Italia Accordo Ministero della salute/ CCM e Regione Marche, may 2009. Available online at: http://www.ccm-network.tt/documenti_Ccm/prg_area5/ Prg_5_Immigrati_metodologia.pdf.pdf [Last Access: March 27, 2019].

19. Bena A, Leombruni R, Giraudo M, Costa G. A new Italian surveillance system for occupational injuries: characteristics and initial results. Am J Ind Med. 2012:55(7):584-92. https://doi.org/10.1002/ajim.22025.

20. Italian National Institute of Statistics (ISTAT). 2011 Population and housing census. 2016. Available at: http://dati-censimentopopolazione.istat.it/Index. aspx?lang=en\&SubSessionld=8dc7157e-a772-40e4-832f150fef83b02c\&themetreeid=-200. Accessed November 10, 2017.

21. Rosenbaum PR, Rubin DB. The central role of propensity score in observational studies for causal effects. Biometrika. 1983;70(1):41-55. https:// doi.org/10.1093/biomet/70.1.41

22. Leombruni R, Mosca M. PSMatching: a SAS macro for treatment effect estimation and missing data imputation based on propensity score matching. Laboratorio Revelli. 2019; Working Paper no. 166.

23. Caliendo $\mathrm{M}$, Kopeinig S. Some practical guidance for the implementation of propensity score matching. J Econ Surv. 2008;22(1):31-72. https://doi.org/10. 1111/j.1467-6419.2007.00527.x.

24. Efron B. Bootstrap methods: another look at the jackknife. Ann Statis. 1979; $7(1): 1-26$

25. Sullivan KM, Dean AG, Mir RA. Statistiche esatte e della massima verosimiglianza adattate da David Martin da un programma di Pascal. Available at: http://www.openepi.com/Menu/OE_Menu.htm. Access date: 31 May 2019.

26. Sianesi B. An evaluation of the Swedish system of active labor market programs in the 1990s. Rev Econ Stat. 2004;86(1):133-55. https://doi.org/10. $1162 / 003465304323023723$.
27. Bena A, Giraudo M, Leombruni R, Costa G. Job tenure and work injuries: a multivariate analysis of the relation with previous experience and differences by age. BMC Public Health. 2013;13:869. https://doi.org/10.1186/ 1471-2458-13-869.

28. Morassaei S, Breslin FC, Shen M, Smith PM. Examining job tenure and losttime claim rates in Ontario, Canada, over a 10-year period, 1999-2008. Occup Environ Med. 2013;70(3):171-8. https://doi.org/10.1136/oemed-2012100743.

29. Fullin G. Unemployment trap or high job turnover? Ethnic penalties and labour market transitions in Italy. Int J Comp Sociol. 2011;52:284-305. https://doi.org/10.1177/0020715211412111.

30. Galon T, Briones-Vozmediano E, Agudelo-Suárez AA, Felt EB, Benavides FG, Ronda E. Understanding sickness presenteeism through the experience of immigrant workers in a context of economic crisis. Am J Ind Med. 2014; 57(8):950-9. https://doi.org/10.1002/ajim.22346.

31. Boone J, van Ours JC. Are recessions good for workplace safety? J Health Econ. 2006;25:1069-93. https://doi.org/10.1016/j.jhealeco.2006.03.002.

32. Mastrangelo G, Rylander R, Buja A, Marangi G, Fadda E, Fedeli U, et al. Work related injuries: estimating the incidence among illegally employed immigrants. BMC Research notes. 2010;3:331. https://doi.org/10.1186/17560500-3-331.

33. Asfaw A, Pana-Cryan R, Rosa R. The business cycle and the incidence of workplace injuries: evidence from the U.S.a. J Saf Res. 2011;42:1-8. https:// doi.org/10.1016/j.jsr.2010.10.008.

34. Bender KA, Mridha HA, Peoples J. Risk compensation for hospital workers: evidence from relative wages of janitors. ILR Rev. 2006;59(2):226-42. https:// doi.org/10.1177/001979390605900203.

35. Ministry of Labor and Social Policy. Sixth annual report - migrants in the labor market in Italy. In: Available at: . Accessed; October 17, 2017.

36. Ahonen EQ, Benavides FG. Injury at work and migrant workers: a priority for a global agenda in occupational health. Occup Environ Med. 2017;74:231-2. https://doi.org/10.1136/oemed-2016-103964.

37. Benach J, Muntaner C, Chung H, Benavides FG. Immigration, employment relations, and health: developing a research agenda. Am J Ind Med. 2010; 53(4):338-43. https://doi.org/10.1002/ajim.20717.

\section{Publisher's Note}

Springer Nature remains neutral with regard to jurisdictional claims in published maps and institutional affiliations.
Ready to submit your research? Choose BMC and benefit from:

- fast, convenient online submission

- thorough peer review by experienced researchers in your field

- rapid publication on acceptance

- support for research data, including large and complex data types

- gold Open Access which fosters wider collaboration and increased citations

- maximum visibility for your research: over $100 \mathrm{M}$ website views per year

At $\mathrm{BMC}$, research is always in progress.

Learn more biomedcentral.com/submissions 